\title{
UTJECAJ STRUKTURE KAPITALA NA PROFITABILNOST POSLOVANJA: ANALIZA SLUČAJA HRVATSKIH, SLOVENSKIH I ČEŠKIH DIONIČKIH DRUŠTAVA
}

\author{
Eleonora Kontuš
}

\author{
UDC / UDK: $330.14: 347.725$ (497.5)(497.4)(437.1/.2) \\ JEL classification / JEL klasifikacija: C21, G32 \\ DOI: https://doi.org/10.22598/pi-be/2021.15.1.41 \\ Preliminary communication / Prethodno priopćenje \\ Received / Primljeno: January 02, 2021. / 02. siječnja 2021. \\ Accepted for publishing / Prihvaćeno za tisak: April 12, 2021 / 12. travnja \\ 2021.
}

\section{Sažetak}

Svrha ovog istraživanja je istražiti empirijske implikacije strukture kapitala na profitabilnost dioničkih društava u odabranim članicama Europske unije. Empirijsko istraživanje je provedeno na uzorku hrvatskih, slovenskih $i$ čeških dioničkih društava čiji su financijski instrumenti uvršteni na tržište kapitala, a u istraživanju je upotrijebljena višestruka linearna regresija na cross sectional podacima. Rezultati istraživanja su pokazali da udjel zadržane dobiti u ukupnom kapitalu i obvezama ima pozitivan $i$ statistički značajan utjecaj na profitabilnost poslovanja dioničkih društava u Republici Hrvatskoj te da udjeli dugoročnog i kratkoročnog duga imaju negativan utjecaj na performansu profitabilnosti. Varijabla udjel zadržane dobiti u ukupnom kapitalu $i$ obvezama ima pozitivan utjecaj na profitabilnost dioničkih društava u Republici Sloveniji, dok udjeli dugoročnog $i$ kratkoročnog duga imaju negativan utjecaj na performansu profitabilnosti. Rezultati empirijskog istraživanja su pokazali da udjel zadržane dobiti ima pozitivan utjecaj na profitabilnost čeških dioničkih društava koji nije statistički značajan. Znanstveni doprinosi istraživanja provedenog u ovom radu se ogledaju u utvrđivanju utjecaja komponenti strukture kapitala na profitabilnost dioničkih društava te da odluke o strukturi kapitala imaju utjecaja na održavanje $i$ unapređenje profitabilnosti dioničkih društava u odabranim članicama Europske unije. Struktura kapitala dioničkih društava u odabranim članicama Europske unije se može smatrati relevantnom jer je utvrđen statistički značajan utjecaj udjela zadržane dobiti na profitabilnost dioničkih društava.

Ključne riječi: struktura kapitala; glavnica; zadržani dobitak; dugoročni dug; profitabilnost poslovanja.

\footnotetext{
${ }^{8}$ dr. sc. Eleonora Kontuš, Grad Kastav, Kastav, Hrvatska, E-mail: eleonora.kontus@ri.tcom.hr
} 


\section{UVOD}

Strukturu kapitala čini kombinacija dugoročnog duga, povlaštenih dionica i običnih dionica uz pomoć koje dioničko društvo pribavlja kapital. Financijsku strukturu čini struktura vlasničkog kapitala poduzeća, dugoročnih dugova i kratkoročnih dugova. Utjecaj financijske strukture na profitabilnost poduzeća se odražava kroz obujam i troškove pozajmljenog kapitala jer povećanje udjela dugoročnog i kratkoročnog duga u financijskoj strukturi poduzeća uzrokuje veće troškove financiranja dugom koji smanjuju profitabilnost poslovanja. Međutim, financiranje dugom pruža dioničkim društvima veći potencijal za razvoj, omogućuje poslovnu ekspanziju i povećanje profitabilnosti poslovanja.

Empirijsko istraživanje je fokusirano na istraživanje utjecaja komponenti strukture kapitala na profitabilnost dioničkih društava čiji su financijski instrumenti uvršteni na tržište kapitala u odabranim članicama Europske unije u godini ulaska Republike Hrvatske u Europsku uniju i nekoliko godina koje su prethodile njenom ulasku u Europsku uniju. Nismo uzeli u razmatranje duži vremenski period i smatramo da će naš empirijski doprinos omogućiti buduća istraživanja u kojima će se usporediti rezultati istraživanja utjecaja strukture kapitala na profitabilnost hrvatskih dioničkih društava nakon ulaska Republike Hrvatske u Europsku uniju s rezultatima našeg istraživanja. Kako bi se istražio utjecaj komponenti strukture kapitala na profitabilnost dioničkih društava, definirana je hipoteza istraživanja: Struktura kapitala ima utjecaja na profitabilnost dioničkih društava u odabranim zemljama članicama Europske unije.

U dosadašnjim empirijskim istraživanjima utjecaja financijske strukture i strukture kapitala na profitabilnost poslovanja najčešće su upotrijebljeni omjeri ukupnog duga i ukupne imovine, dugoročnog duga i ukupne imovine te kratkoročnog duga $\mathrm{i}$ ukupne imovine kao pokazatelji financijske strukture. Ovo se istraživanje razlikuje od prethodnih istraživanja jer je istražen utjecaj svih komponenti financijske strukture na profitabilnost dioničkih društava. Pojedinačne komponente financijske strukture čine udjeli temeljnog kapitala, zadržane dobiti, dugoročnih obveza i kratkoročnih obveza u ukupnom kapitalu i obvezama.

U dosadašnjim istraživanjima utjecaja financijske strukture na profitabilnost poslovanja ne razmatraju se utjecaji temeljnog kapitala i zadržane dobiti na profitabilnost poslovanja što predstavlja veliko ograničenje takvih istraživanja jer bi varijable udjeli temeljnog kapitala i zadržane dobiti trebale imati statistički značajan utjecaj na profitabilnost poslovanja, te se ne mogu isključiti pri istraživanju.

Znanstveni doprinosi istraživanja provedenog u ovom radu se ogledaju $u$ sljedećem: utvrđen je statistički značajan utjecaj određenih komponenti strukture kapitala na profitabilnost dioničkih društava u odabranim članicama Europske unije, odabirom komponenti strukture kapitala dionička društva mogu utjecati na održavanje i unapređenje profitabilnosti poslovanja, a utjecaj strukture kapitala na financijske performanse se ne može istražiti samo kao utjecaj ukupne zaduženosti na financijske performanse jer bi varijabla udjel zadržane dobiti trebala imati statistički značajan utjecaj na profitabilnost poduzeća. Struktura kapitala dioničkih društava se može smatrati 
relevantnom jer je u ovom istraživanju utvrđen statistički značajan utjecaj komponenti strukture kapitala odnosno udjela zadržane dobiti na performansu profitabilnosti.

\section{PREGLED DOSADAŠNJIH ISTRAŽIVANJA}

Financijsku strukturu poduzeća čine vlastiti kapital, dugoročni dug i kratkoročni dug kojima se financira dugotrajna i kratkotrajna imovina poduzeća. U empirijskim straživanjima (Weill, 2008; Margaritis i Psillaki, 2010; Kebewar, 2012; Gabrijelčić et al., 2013) se kao varijable financijske strukture koriste sljedeći pokazatelji: odnos ukupnih obveza i imovine, odnos kratkoročnog duga i ukupne imovine, odnos dugoročnog duga i ukupne imovine, odnos duga i vlastitog kapitala te odnos dugoročnog duga i vlastitog kapitala.

Rezultati dosadašnjih istraživanja utjecaja financijske strukture i strukture kapitala na profitabilnost poslovanja nisu konzistentni s obzirom na smjer i jačinu veze između pokazatelja zaduženosti i profitabilnosti. Razlog je u tome što se $u$ istraživanjima (Weill, 2008; Nunes et al., 2009; Margaritis i Psillaki, 2010; Kebewar, 2012; Gabrijelčić et al., 2013: Chandrapala i Knapkova, 2013) koriste različiti pokazatelji zaduženosti i različiti pokazatelji profitabilnosti.

U empirijskim istraživanjima (Gleason et al., 2000; Nunes et al., 2009; Margaritis i Psillaki, 2010; Kebewar, 2012; Gabrijelčić et al., 2013; Chandrapala i Knapkova, 2013) se kao pokazatelj financijske strukture koristi stupanj zaduženosti odnosno omjer ukupnog duga i ukupne imovine. Empirijska istraživanja (Gleason et al., 2000; Eriotis et al., 2002; Goddard et al., 2005; Nunes et al., 2009; Chandrapala i Knapkova, 2013; Vatavu, 2015) su sugerirala negativan utjecaj financiranja dugom na profitabilnost poslovanja. Stupanj zaduženosti poduzeća ima negativan utjecaj na profitabilnost poslovanja jer veća zaduženost poduzeća generira veće troškove financijskih poremećaja i troškove agenata koji su povezani uz financiranje dugom.

Gleason et al. (2000) su proveli istraživanje na uzorku poduzeća u zemljama Europske unije. Rezultati istraživanja su pokazali da postoji negativna veza između stupnja zaduženosti i profitabilnosti poslovanja koja je statistički značajna. U empirijskom istraživanju koje su proveli Eriotis et al. (2002) utvrđeno je da postoji negativna veza između omjera duga i glavnice na profitabilnost poduzeća. Stoga se može ustvrditi da su troškovi financiranja dugom veći nego dobit od investicija ili da su poduzeća koja primjenjuju teoriju hijerarhije financijskih izbora i preferiraju financiranje iz zadržane dobiti profitabilnija nego poduzeća koja koriste financiranje dugom.

Goddard et al. (2005) su proveli istraživanje na uzorku poduzeća u Belgiji, Francuskoj, Italiji i Velikoj Britaniji. Rezultati njihovih istraživanja su pokazali da je veza između omjera dugoročnog duga i glavnice i profitabilnosti istraživanih poduzeća negativna. Nunes et al. (2009) su proveli istraživanje na uzorku poduzeća u Portugalu. Rezultati empirijskog istraživanja sugeriraju negativan utjecaj financiranja dugom na profitabilnost poslovanja.

Gabrijelčič et al. (2013) su proveli empirijsko istraživanje utjecaja financiranja dugom na profitabilnost poduzeća u Republici Sloveniji. Rezultati istraživanja sugeriraju 
negativan i statistički značajan utjecaj zaduženosti na profitabilnost poduzeća. Chandrapala i Knapkova (2013) su proveli istraživanje na uzorku čeških poduzeća, a rezultati istraživanja su pokazali negativnu vezu između financiranja dugom i profitabilnosti istraživanih poduzeća.

Močnik i Širec (2015) su istražile povezanost između profitabilnosti, veličine poduzeća, omjera zaduženosti i troškova rada na uzorku poduzeća u Republici Sloveniji. Rezultati istraživanja sugeriraju negativnu vezu između veličine poduzeća i stupnja zaduženosti i profitabilnosti poslovanja te da najveći utjecaj na profitabilnost poslovanja ima stupanj zaduženosti. Veza između stupnja zaduženosti i profitabilnosti poslovanja je negativna i statistički značajna. Vatavu (2015) je istražila povezanost između strukture kapitala i financijskih performansi na uzorku rumunjskih poduzeća. Rezultati istraživanja su pokazali da dionička glavnica ima pozitivan utjecaj na profitabilnost poslovanja.

Kontuš (2012) je istražila povezanost između kratkoročnog duga i profitabilnosti mjerene pokazateljem povrat na imovinu (ROA) u velikim poduzećima u Republici Hrvatskoj. Rezultati istraživanja su pokazali da je korelacija između razine kratkoročnog duga i profitabilnosti mjerene pokazateljem ROA negativna i da povećanje razine kratkoročnog duga dovodi do smanjenja profitabilnosti u velikim poduzećima u Republici Hrvatskoj. Kontuš (2018) je istražila financijsku strukturu malih i srednjih poduzeća u Republici Hrvatskoj te povezanost između kratkoročnog i dugoročnog duga i profitabilnosti poslovanja. Rezultati istraživanja su pokazali da postoji negativna korelacija između dugoročnog duga i profitabilnosti mjerene pokazateljem povrat na imovinu (ROA) te između kratkoročnog duga i pokazatelja ROA.

Rezultati dosadašnjih istraživanja sugeriraju i pozitivnu vezu između stupnja zaduženosti i profitabilnosti poslovanja. Pozitivna veza između financiranja dugom i profitabilnosti poslovanja može ukazivati da interno generirana sredstva nisu dovoljna za financiranje investicijskih projekata, te da poduzeća pribavljaju dodatni kapital zaduživanjem. Baum et al. (2006), Berger i Bonaccorsi (2006) te Margaritis i Psillaki (2010) su pokazali pozitivan utjecaj zaduženosti poduzeća na profitabilnost poslovanja. Berger i Bonaccorsi (2006) su proveli istraživanje na uzorku financijskih poduzeća u Sjedinjenim Američkim Državama. Rezultati njihovih istraživanja su pokazali da veći udjel duga i manji udjel glavnice u strukturi kapitala dovode do povećanja profitabilnosti poslovanja. Margaritis i Psillaki (2010) su proveli istraživanje utjecaja financiranja dugom i vlasničke strukture na financijske performanse na uzorku francuskih poduzeća. Rezultati njihovih istraživanja su pokazali da povećanje stupnja zaduženosti ima pozitivan utjecaj na profitabilnost poduzeća.

Weill (2008) je istražio institucionalne čimbenike i njihov utjecaj na vezu između financiranja dugom i financijskih performansi te je dokazao da institucionalni čimbenici mogu objasniti razlike u povezanosti između zaduženosti i financijskih performansi u europskim zemljama. Kebewar (2012) je proveo istraživanje utjecaja zaduženosti na profitabilnost poduzeća i dokazao da omjer duga nema utjecaja na profitabilnost francuskih poduzeća.

Rezultati empirijskih istraživanja utjecaja financijske strukture i strukture kapitala na profitabilnost poduzeća su različiti s obzirom na smjer i jačinu veze između stupnja zaduženosti i profitabilnosti poduzeća. Utjecaj stupnja zaduženosti na 
profitabilnost poduzeća je različit u različitim zemljama i institucionalnim okruženjima jer obilježja institucionalnog okruženja, posebno obilježja financijskog sustava, poreznog sustava i pravnog sustava, imaju utjecaja na vezu između zaduženosti i profitabilnosti poduzeća.

\section{METODOLOŠKI OKVIR ISTRAŽIVANJA}

\subsection{Opis uzorka podataka}

U empirijskom istraživanju su korišteni podaci iz sljedećih članica Europske unije: Republike Hrvatske, Republike Slovenije i Češke Republike. Hrvatska, Slovenija i Češka Republika su odabrane za usporedbu jer su Češka Republika, Slovenija i Hrvatska nastale podjelom zemalja koje su pripadale istom društveno ekonomskom sustavu, te su sve tri zemlje bile uključene u tranzicijske procese. Početni uzorak uključivao je 228 dioničkih društava čiji su vrijednosni papiri uvršteni na Zagrebačku burzu i Ljubljansku burzu te Burzu u Pragu. U Tablici 1. su prikazani početni uzorak i konačni uzorak dioničkih društava čiji su vrijednosni papiri uvršteni na tržište kapitala te udio istraživanih poduzeća u početnom uzorku.

Tablica 1. Struktura uzorka podataka

\begin{tabular}{|l|l|l|l|}
\hline Dionička društva & $\begin{array}{l}\text { Početni } \\
\text { uzorak }\end{array}$ & $\begin{array}{l}\text { Konačni } \\
\text { uzorak }\end{array}$ & $\mathbf{\%}$ \\
\hline Republika Hrvatska & 146 & 89 & 60,96 \\
\hline Republika Slovenija & 56 & 30 & 53,57 \\
\hline Češka Republika & 26 & 24 & 92,31 \\
\hline Ukupno & 228 & 143 & 62,72 \\
\hline
\end{tabular}

Dionička društva u financijskom sektoru su izuzeta iz uzorka jer za njih vrijede posebna pravila i imaju različitu strukturu bilance u odnosu na nefinancijska dionička društva. Dionička društva čije su vrijednosti kapitala negativne su izostavljena iz uzorka kao i dionička društva kojima nedostaju financijske informacije za određenu godinu. Nakon uvažavanja svih kriterija odabira, konačan uzorak obuhvaća 143 dionička društva čiji su vrijednosni papiri uvršteni na Zagrebačku burzu, Ljubljansku burzu i Burzu u Pragu.

\subsection{Definiranje i opis varijabli}

Nezavisne varijable upotrijebljene u empirijskom istraživnaju čine udjeli pojedinačnih komponenti financijske strukture u ukupnom kapitalu i obvezama, a prikazane su u Tablici 2. 
Tablica 2. Definiranje i opis nezavisnih varijabli

\begin{tabular}{|c|c|}
\hline Nezavisne varijable & Definicija varijable \\
\hline $\begin{array}{c}\text { Udjel temeljnog kapitala u } \\
\text { ukupnom kapitalu i obvezama }\end{array}$ & Temeljni kapital/ukupni kapital i obveze \\
\hline $\begin{array}{c}\text { Udjel zadržane dobiti i rezervi u } \\
\text { ukupnom kapitalu i obvezama }\end{array}$ & Zadržana dobit i rezerve /ukupni kapital i \\
obveze
\end{tabular}

Zavisne varijable korištene $\mathrm{u}$ empirijskom istraživanju čine različiti pokazatelji profitabilnosti poslovanja.

Tablica 3. Definiranje varijabli i opis pokazatelja profitabilnosti

\begin{tabular}{|c|c|}
\hline Zavisne varijable & Definicija varijabli \\
\hline Pokazatelji profitabilnosti & \\
\hline Neto profitna marža & Dobit razdoblja/ukupni prihod \\
\hline Stopa prinosa na ukupnu imovinu (ROA) & Dobit razdoblja/ukupna imovina \\
\hline Stopa prinosa na vlastiti kapital (ROE) & Dobit razdoblja/kapital \\
\hline
\end{tabular}

Zavisne varijable se iskazuju kao funkcija nezavisnih varijabli.

Profitabilnost $=f\left(E_{B V}, R E_{B V}, L T D_{B V}\right)$

Profitabilnost $=f\left(L T D_{B V}, S T D_{B V}\right)$

\subsection{Metodološki okvir empirijskog istraživanja}

U empirijskom istraživanju je upotrijebljena višestruka linearna regresija na cross sectional podacima u 2010, 2011, 2012. i 2013. godini, a napravljena je s ciljem analize utjecaja komponenti strukture kapitala na performansu profitabilnosti i utvrđivanja nezavisnih varijabli koje su statistički značajne za povećanje profitabilnosti poslovanja.

Model višestruke linearne regresije se može predočiti jednadžbom (Bahovec i Erjavec, 2009):

$$
y=\beta_{0}+\beta_{1} \times x_{1}+\beta_{2} \times x_{2}+\cdots+\beta_{j} \times x_{j}+\cdots+\beta_{k} \times x_{k}+\varepsilon .
$$

pri čemu je $y$ zavisna, regresand ili endogena varijabla, a $x_{1}, x_{2}, \ldots, x_{k}$ su nezavisne, regresorske ili egzogene varijable, dok su $\beta_{0}, \beta_{1}, \ldots, \beta_{k}$ nepoznati parametri, a $\varepsilon$ je slučajna varijabla.

Utjecaj pojedinačnih komponenti financijske strukture na performansu profitabilnosti je istražen $\mathrm{s}$ aspekta utjecaja varijabli strukture kapitala i varijabli financiranja dugom na performansu profitabilnosti. Performansa profitabilnosti je analizirana temeljem sljedećih empirijskih modela:

Formiran je Model višestruke linearne regresije I u kojem je zavisna varijabla pokazatelj profitabilnosti: neto profitna marža, ROA ili ROE, dok su nezavisne varijable: 
udjel temeljnog kapitala u ukupnom kapitalu i obvezama, udjel zadržane dobiti i rezervi u ukupnom kapitalu i obvezama te udjel dugoročnih obveza u ukupnom kapitalu i obvezama.

$$
y=\alpha+\beta_{1} \times E_{B V}+\beta_{2} \times R E_{B V}+\beta_{3} \times L T D_{B V}
$$

gdje je $y$ pokazatelj profitabilnosti, $\alpha$ konstanta, $\beta_{n}$ koeficijent regresije, $E_{B V}$ udjel temeljnog kapitala u ukupnom kapitalu i obvezama, $R E_{B V}$ udjel zadržane dobiti i rezervi u ukupnom kapitalu i obvezama i $L T D_{B V}$ udjel dugoročnih obveza u ukupnom kapitalu i obvezama.

Formiran je Model višestruke linearne regresije II u kojem je zavisna varijabla pokazatelj profitabilnosti: neto profitna marža, ROA ili ROE, dok su nezavisne varijable: udjel dugoročnih obveza u ukupnom kapitalu i obvezama i udjel kratkoročnih obveza u ukupnom kapitalu i obvezama.

$$
y=\alpha+\beta_{1} \times L T D_{B V}+\beta_{2} \times S T D_{B V}
$$

gdje je $y$ pokazatelj profitabilnosti, $\alpha$ konstanta, $\beta_{n}$ koeficijent regresije, $L T D_{B V}$ udjel dugoročnih obveza u ukupnom kapitalu i obvezama i $S T D_{B V}$ udjel kratkoročnih obveza u ukupnom kapitalu i obvezama.

Pri korištenju višestruke linearne regresije potrebno je ispuniti polazne pretpostavke u linearnom regresijskom modelu i u ovom su radu provedeni odgovarajući dijagnostički testovi. Jacque-Bera test je korišten za ispitivanje normalnosti distribucije. Problem multikolinearnosti regresorskih varijabli je istražen korištenjem standardnih pokazatelja multikolinearnosti: faktora inflacije varijance (VIF) i ekvivalentnog pokazatelja TOL (Tolerance). Problem postojanja autokorelacije slučajnih varijabli u regresijskom modelu je istražen korištenjem Durbin-Watson testa. Za provođenje empirijske analize korišten je programski paket IBM SPSS V24.

\section{EMPIRIJSKO ISTRAŽIVANJE: ANALIZA UTJECAJA FINANCIJSKE STRUKTURE NA PERFORMANSU PROFITABILNOSTI}

Komponente financijske strukture i njihov utjecaj na performansu profitabilnosti su istraženi s aspekta utjecaja strukture kapitala na profitabilnost i utjecaja varijabli financiranja dugom na profitabilnost dioničkih društava.

Modeli su korektni sa stajališta polaznih pretpostavki modela koje su ispunjene. Na temelju Jacque-Bera testa se može zaključiti da su rezidualna odstupanja normalno distribuirana. Pokazatelji multikolinearnosti faktor inflacije varijance VIF i ekvivalentni pokazatelj TOL pokazuju da problem multikolinearnosti nije prisutan u našoj analizi. Rezultati Durbin-Watson testa pokazuju da u postavljenim modelima ne postoji autokorelacija. Slijedom toga utvrdili smo da problemi multikolinearnosti i autokorelacije nisu prisutni u našoj analizi. 
Rezultati analize utjecaja komponenti strukture kapitala na profitabilnost poslovanja dioničkih društava u Republici Hrvatskoj modelom višestruke linearne regresije - Model I su prikazani u Tablici 4.

Tablica 4. Rezultati analize utjecaja strukture kapitala na profitabilnost dioničkih društava u Republici Hrvatskoj modelom višestruke linearne regresije -Model I

\begin{tabular}{|c|c|c|c|c|}
\hline Godina & 2010 & 2011 & 2012 & 2013 \\
\hline \multicolumn{5}{|c|}{ Zavisna varijabla neto profitna marža } \\
\hline Koeficijent determinacije $R^{2}$ & 0.19 & 0.097 & 0.218 & 0.094 \\
\hline Durbin-Watson Stat & 2.160 & 1.907 & 1.833 & 2.094 \\
\hline \multicolumn{5}{|l|}{ Nezavisne varijable } \\
\hline \multicolumn{5}{|l|}{ Udjel temeljnog kapitala } \\
\hline Koeficijent regresije & 0.339 & 0.238 & 0.771 & 0.593 \\
\hline P-vrijednost & 0.033 & 0.311 & 0.000 & 0.034 \\
\hline TOL & .622 & .610 & .708 & .779 \\
\hline$V I F$ & 1.607 & 1.638 & 1.413 & 1.284 \\
\hline \multicolumn{5}{|l|}{ Udjel zadržane dobiti i rezervi } \\
\hline Koeficijent regresije & 0.727 & 0.539 & 0.966 & 0.760 \\
\hline P-vrijednost & 0.000 & $\mathbf{0 . 0 3 7}$ & 0.000 & 0.011 \\
\hline TOL & .604 & .601 & .666 & .745 \\
\hline$V I F$ & 1.654 & 1.664 & 1.502 & 1.343 \\
\hline \multicolumn{5}{|l|}{ Udjel dugoročnih obveza } \\
\hline Koeficijent regresije & 0.196 & -0.296 & 0.357 & -0.022 \\
\hline P-vrijednost & 0.349 & 0.342 & 0.173 & 0.956 \\
\hline TOL & .773 & .753 & .813 & .907 \\
\hline$V I F$ & 1.294 & 1.328 & 1.230 & 1.103 \\
\hline \multicolumn{5}{|l|}{ Zavisna varijabla ROA } \\
\hline Koeficijent determinacije $R^{2}$ & 0.307 & 0.193 & 0.288 & 0.066 \\
\hline Durbin-Watson Stat & 2.151 & 2.041 & 1.918 & 1.958 \\
\hline \multicolumn{5}{|l|}{ Nezavisne varijable } \\
\hline Udjel temeljnog kapitala & & & & \\
\hline Koeficijent regresije & 0.085 & 0.091 & 0.206 & 0.018 \\
\hline$P$-vrijednost & 0.011 & 0.012 & 0.000 & 0.777 \\
\hline TOL & .622 & .610 & .708 & .779 \\
\hline$V I F$ & 1.607 & 1.638 & 1.413 & 1.284 \\
\hline \multicolumn{5}{|l|}{ Udjel zadržane dobiti i rezervi } \\
\hline Koeficijent regresije & 0.209 & 0.162 & 0.311 & 0.144 \\
\hline P-vrijednost & 0.000 & 0.000 & 0.000 & 0.035 \\
\hline$T O L$ & .604 & .601 & .666 & .745 \\
\hline$V I F$ & 1.654 & 1.664 & 1.502 & 1.343 \\
\hline \multicolumn{5}{|l|}{ Udjel dugoročnih obveza } \\
\hline Koeficijent regresije & 0.066 & 0.017 & 0.116 & -0.028 \\
\hline P-vrijednost & 0.133 & 0.725 & 0.081 & 0.765 \\
\hline TOL & .773 & .753 & .813 & .907 \\
\hline$V I F$ & 1.294 & 1.328 & 1.230 & 1.103 \\
\hline \multicolumn{5}{|l|}{ Zavisna varijabla ROE } \\
\hline Koeficijent determinacije $R^{2}$ & 0.122 & 0.229 & 0.276 & 0.238 \\
\hline
\end{tabular}




\begin{tabular}{|l|c|c|c|c|}
\hline Durbin-Watson Stat & 2.298 & 2.064 & 2.089 & 1.898 \\
\hline Nezavisne varijable & & & & \\
\hline Udjel temeljnog kapitala & & & & \\
Koeficijent regresije & 0.288 & 0.084 & $\mathbf{0 . 7 6 1}$ & $\mathbf{1 . 5 1 3}$ \\
P-vrijednost & 0.422 & 0.738 & $\mathbf{0 . 0 2 8}$ & $\mathbf{0 . 0 0 6}$ \\
TOL & .622 & .610 & .708 & .779 \\
VIF & 1.607 & 1.638 & 1.413 & 1.284 \\
\hline Udjel zadržane dobiti i rezervi & & & & \\
Koeficijent regresije & $\mathbf{0 . 7 8 3}$ & $\mathbf{1 . 0 6 0}$ & $\mathbf{1 . 9 6 7}$ & $\mathbf{2 . 8 7 5}$ \\
P-vrijednost & $\mathbf{0 . 0 4 3}$ & $\mathbf{0 . 0 0 0}$ & $\mathbf{0 . 0 0 0}$ & $\mathbf{0 . 0 0 0}$ \\
TOL & .604 & .601 & .666 & .745 \\
VIF & 1.654 & 1.664 & 1.502 & 1.343 \\
\hline Udjel dugoročnih obveza & & & & \\
Koeficijent regresije & -0.276 & -0.161 & 0.069 & 0.668 \\
P-vrijednost & 0.562 & 0.627 & 0.877 & 0.389 \\
TOL & .773 & .753 & .813 & .907 \\
VIF & 1.294 & 1.328 & 1.230 & 1.103 \\
\hline
\end{tabular}

Izvor: izračun autora

Rezultati regresijske analize pokazuju da varijabla udjel zadržane dobiti i rezervi u ukupnom kapitalu i obvezama ima pozitivan i statistički značajan utjecaj na performansu profitabilnosti mjerenu pokazateljima neto profitna marža, ROA i ROE na razini od $1 \%$ i $5 \%$. Povećanjem udjela zadržane dobiti i rezervi povećava se profitabilnost hrvatskih dioničkih društava mjerena pokazateljima neto profitna marža, ROA i ROE. Varijabla udjel temeljnog kapitala ima pozitivan i statistički značajan utjecaj na performansu profitabilnosti mjerenu pokazateljem ROA na razini od 1\% u 2010., 2011. i 2012. godini, dok u 2010., 2012. i 2013. godini ima pozitivan i statistički značajan utjecaj na profitabilnost mjerenu pokazateljem neto profitna marža na razini od $5 \%$ i $1 \%$. Koeficijenti determinacije pokazuju kako je od $6.6 \%$ do $30.7 \%$ varijacija zavisne varijable profitabilnosti mjerene pokazateljima neto profitna marža, ROA i ROE objašnjeno pomoću ocijenjenih regresijskih modela.

Rezultati analize utjecaja financiranja dugom na profitabilnost dioničkih društava u Republici Hrvatskoj modelom višestruke linearne regresije - Model II su prikazani u Tablici 5. 
Tablica 5. Rezultati analize utjecaja financiranja dugom na profitabilnost dioničkih društava u Hrvatskoj modelom višestruke linearne regresije - Model II

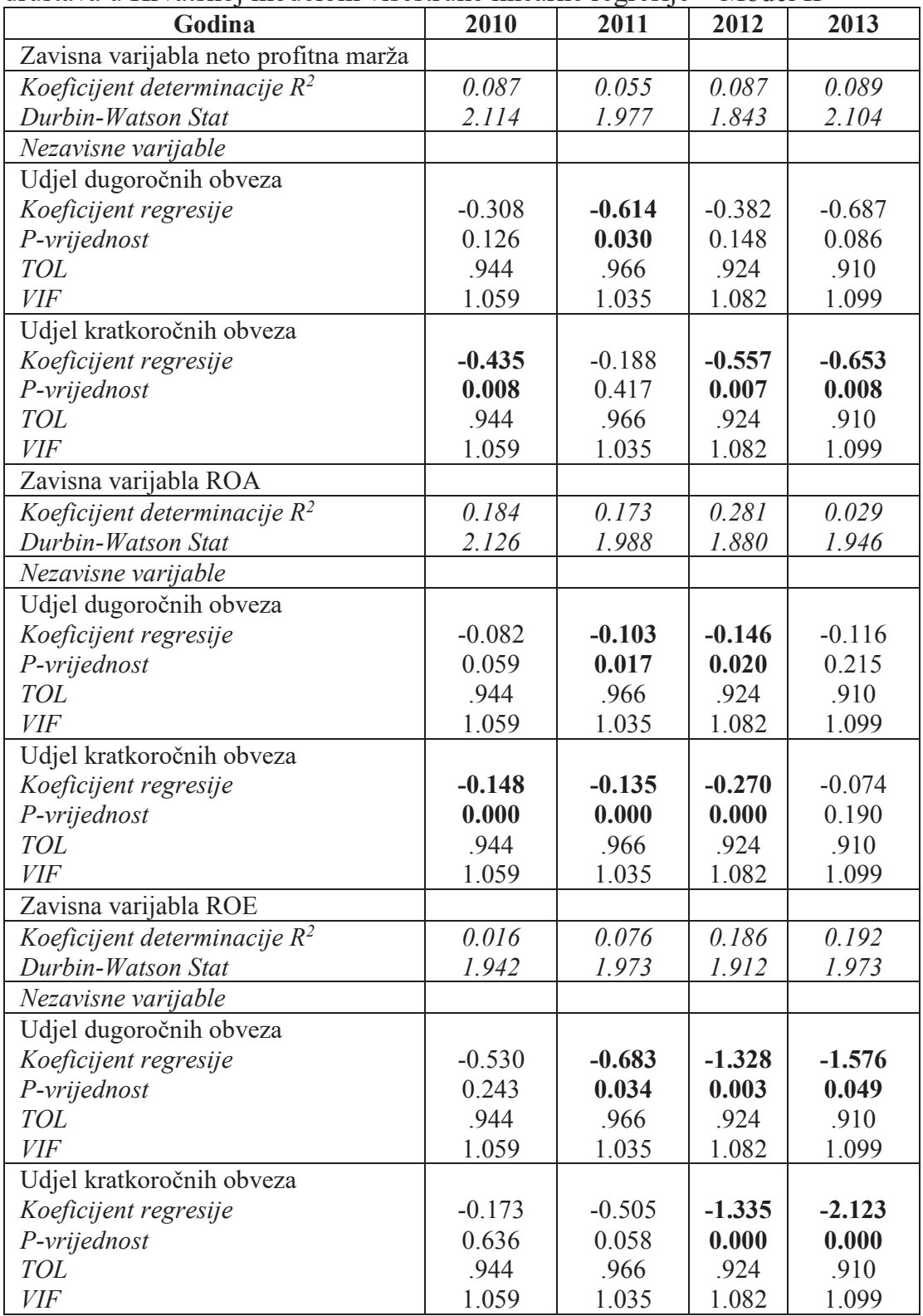

Izvor: izračun autora 
Rezultati regresijske analize pokazuju da varijabla udjel dugoročnih obveza ima negativan i statistički značajan utjecaj na performansu profitabilnosti mjerenu pokazateljem neto profitna marža na razini od 5\% u 2011. godini. Varijabla udjel kratkoročnih obveza ima negativan i statistički značajan utjecaj na performansu profitabilnosti mjerenu pokazateljem neto profitna marža na razini od 1\% u 2010., 2012. i 2013. godini. Varijabla udjel kratkoročnih obveza ima negativan i statistički značajan utjecaj na performansu profitabilnosti mjerenu pokazateljem ROA na razini od $1 \% \mathrm{u}$ 2010., 2011. i 2012. godini.

Varijabla udjel dogoročnih obveza u ukupnom kapitalu i obvezama ima negativan i statistički značajan utjecaj na performansu profitabilnosti mjerenu pokazateljem ROE na razini od 5\% i 1\% u 2011., 2012. i 2013. godini. Varijabla udjel kratkoročnih obveza ima negativan i statistički značajan utjecaj na profitabilnost mjerenu pokazateljem ROE na razini od 1\% u 2012. i 2013. godini. Koeficijenti determinacije pokazuju kako je od $1.6 \%$ do $28.1 \%$ varijacija zavisne varijable profitabilnosti mjerene pokazateljima neto profitna marža, ROA i ROE objašnjeno pomoću ocijenjenih regresijskih modela.

Rezultati analize utjecaja komponenti strukture kapitala na profitabilnost dioničkih društava čiji su financijski instrumenti uvršteni na tržište kapitala u Republici Sloveniji modelom višestruke linearne regresije - Model I su prikazani u Tablici 6.

Tablica 6. Rezultati analize utjecaja strukture kapitala na profitabilnost dioničkih društava u Sloveniji modelom višestruke linearne regresije - Model I

\begin{tabular}{|l|c|c|c|c|}
\hline Godina & $\mathbf{2 0 1 0}$ & $\mathbf{2 0 1 1}$ & $\mathbf{2 0 1 2}$ & $\mathbf{2 0 1 3}$ \\
\hline Zavisna varijabla neto profitna marža & & & & \\
\hline Koeficijent determinacije $R^{2}$ & 0.653 & 0.464 & 0.474 & 0.143 \\
Durbin-Watson Stat & 1.675 & 1.786 & 2.090 & 1.871 \\
\hline Nezavisne varijable & & & & \\
\hline Udjel temeljnog kapitala & & & & \\
Koeficijent regresije & $\mathbf{4 . 6 7 7}$ & $\mathbf{0 . 3 0 8}$ & $\mathbf{0 . 2 4 6}$ & 0.535 \\
P-vrijednost & $\mathbf{0 . 0 0 0}$ & $\mathbf{0 . 0 0 0}$ & $\mathbf{0 . 0 0 4}$ & 0.642 \\
TOL & .485 & .801 & .518 & .549 \\
VIF & 2.062 & 1.249 & 1.930 & 1.822 \\
\hline Udjel zadržane dobiti i rezervi & & & & \\
Koeficijent regresije & 0.591 & $\mathbf{0 . 1 7 0}$ & $\mathbf{0 . 3 0 2}$ & 1.712 \\
$P$-vrijednost & 0.343 & $\mathbf{0 . 0 1 0}$ & $\mathbf{0 . 0 0 0}$ & 0.091 \\
TOL & .344 & .830 & .529 & .562 \\
VIF & 2.909 & 1.204 & 1.891 & 1.780 \\
\hline Udjel dugoročnih obveza & & & & \\
Koeficijent regresije & -0.543 & -0.023 & $\mathbf{0 . 1 8 4}$ & 0.252 \\
P-vrijednost & 0.486 & 0.796 & $\mathbf{0 . 0 3 8}$ & 0.852 \\
TOL & .456 & .876 & .550 & .537 \\
VIF & 2.192 & 1.142 & 1.818 & 1.861 \\
\hline Zavisna varijabla ROA & & & & \\
\hline Koeficijent determinacije $R^{2}$ & 0.375 & 0.246 & 0.418 & 0.256 \\
Durbin-Watson Stat & 1.239 & 1.272 & 1.356 & 1.870 \\
\hline Nezavisne varijable & & & & \\
\hline
\end{tabular}




\begin{tabular}{|l|c|c|c|c|}
\hline Udjel temeljnog kapitala & & & & \\
Koeficijent regresije & $\mathbf{0 . 1 5 9}$ & 0.046 & 0.080 & 0.270 \\
P-vrijednost & $\mathbf{0 . 0 3 0}$ & 0.239 & 0.122 & 0.234 \\
TOL & .485 & .801 & .518 & .549 \\
VIF & 2.062 & 1.249 & 1.930 & 1.822 \\
\hline Udjel zadržane dobiti i rezervi & & & & \\
Koeficijent regresije & 0.013 & $\mathbf{0 . 0 8 0}$ & $\mathbf{0 . 1 6 7}$ & $\mathbf{0 . 5 0 9}$ \\
P-vrijednost & 0.798 & $\mathbf{0 . 0 1 6}$ & $\mathbf{0 . 0 0 0}$ & $\mathbf{0 . 0 1 2}$ \\
TOL & .344 & .830 & .529 & .562 \\
VIF & 2.909 & 1.204 & 1.891 & 1.780 \\
\hline Udjel dugoročnih obveza & & & & \\
Koeficijent regresije & -0.085 & -0.024 & 0.071 & 0.146 \\
P-vrijednost & 0.189 & 0.600 & 0.204 & 0.582 \\
TOL & .456 & .876 & .550 & .537 \\
VIF & 2.192 & 1.142 & 1.818 & 1.861 \\
\hline Zavisna varijabla ROE & & & & \\
\hline Nezavisne varijable & & & & \\
\hline Koeficijent determinacije $R^{2}$ & 0.308 & 0.234 & 0.224 & 0.259 \\
Durbin-Watson Stat & 1.447 & 1.319 & 2.003 & 1.721 \\
\hline Udjel temeljnog kapitala & & & & \\
Koeficijent regresije & -0.589 & -0.191 & -0.300 & 1.270 \\
P-vrijednost & 0.628 & 0.773 & 0.822 & 0.524 \\
TOL & .485 & .801 & .518 & .549 \\
VIF & 2.062 & 1.249 & 1.930 & 1.822 \\
\hline Udjel zadržane dobiti i rezervi & & & & \\
Koeficijent regresije & 1.399 & $\mathbf{1 . 2 7 8}$ & 2.183 & $\mathbf{4 . 3 8 1}$ \\
P-vrijednost & 0.119 & $\mathbf{0 . 0 2 5}$ & 0.059 & $\mathbf{0 . 0 1 5}$ \\
TOL & .344 & .830 & .529 & .562 \\
VIF & 2.909 & 1.204 & 1.891 & 1.780 \\
\hline Udjel dugoročnih obveza & & & & \\
Koeficijent regresije & -0.340 & -0.286 & 0.750 & 1.047 \\
P-vrijednost & 0.758 & 0.716 & 0.610 & 0.655 \\
TOL & .456 & .876 & .550 & .537 \\
VIF & 2.192 & 1.142 & 1.818 & 1.861 \\
\hline
\end{tabular}

Izvor: izračun autora

Rezultati regresijske analize pokazuju da varijabla udjel temeljnog kapitala ima pozitivan i statistički značajan utjecaj na performansu profitabilnosti mjerenu pokazateljem neto profitna marža u 2010., 2011. i 2012. godini, dok varijabla udjel zadržane dobiti i rezervi ima pozitivan i statistički značajan utjecaj u 2011. i 2012. godini. Regresorska varijabla udjel zadržane dobiti i rezervi ima pozitivan i statistički značajan utjecaj na profitabilnost mjerenu pokazateljem ROA u 2011., 2012. i 2013. godini uz razinu signifikantnosti od 1\%. Koeficijenti determinacije pokazuju kako je od $14.3 \%$ do $65.3 \%$ varijacija varijable profitabilnosti mjerene pokazateljima neto profitna marža, ROA i ROE objašnjeno pomoću ocijenjenih regresijskih modela. 
Rezultati analize utjecaja financiranja dugom na profitabilnost poslovanja dioničkih društava čiji su financijski instrumenti uvršteni na tržište kapitala u Republici Sloveniji modelom višestruke linearne regresije - Model II su prikazani u Tablici 7.

Tablica 7. Rezultati analize utjecaja financiranja dugom na profitabilnost dioničkih društava u Sloveniji modelom višestruke linearne regresije - Model II

\begin{tabular}{|c|c|c|c|c|}
\hline Godina & 2010 & 2011 & 2012 & 2013 \\
\hline \multicolumn{5}{|c|}{ Zavisna varijabla neto profitna marža } \\
\hline \multicolumn{5}{|l|}{ Nezavisne varijable } \\
\hline Koeficijent determinacije $R^{2}$ & 0.025 & 0.270 & 0.452 & 0.098 \\
\hline Durbin-Watson Stat & 2.057 & 1.701 & 2.122 & 1.997 \\
\hline \multicolumn{5}{|l|}{ Udjel dugoročnih obveza } \\
\hline Koeficijent regresije & -0.545 & -0.149 & -0.090 & -0.905 \\
\hline P-vrijednost & 0.531 & 0.128 & 0.165 & 0.369 \\
\hline TOL & .992 & .999 & .991 & .999 \\
\hline$V I F$ & 1.008 & 1.001 & 1.009 & 1.001 \\
\hline \multicolumn{5}{|l|}{ Udjel kratkoročnih obveza } \\
\hline Koeficijent regresije & -0.597 & -0.230 & -0.285 & 1.365 \\
\hline P-vrijednost & 0.557 & 0.012 & 0.000 & 0.151 \\
\hline TOL & .992 & .999 & .991 & .999 \\
\hline$V I F$ & 1.008 & 1.001 & 1.009 & 1.001 \\
\hline \multicolumn{5}{|l|}{ Zavisna varijabla ROA } \\
\hline \multicolumn{5}{|l|}{ Nezavisne varijable } \\
\hline Koeficijent determinacije $R^{2}$ & 0.078 & 0.111 & 0.309 & 0.215 \\
\hline Durbin-Watson Stat & 1.427 & 1.999 & 1.330 & 1.986 \\
\hline \multicolumn{5}{|l|}{ Udjel dugoročnih obveza } \\
\hline Koeficijent regresije & -0.077 & -0.055 & -0.055 & -0.251 \\
\hline P-vrijednost & 0.142 & 0.234 & 0.218 & 0.204 \\
\hline TOL & .992 & .999 & .991 & .999 \\
\hline$V I F$ & 1.008 & 1.001 & 1.009 & 1.001 \\
\hline \multicolumn{5}{|l|}{ Udjel kratkoročnih obveza } \\
\hline Koeficijent regresije & -0.013 & -0.054 & -0.143 & -0.436 \\
\hline P-vrijednost & 0.832 & 0.193 & 0.002 & 0.022 \\
\hline TOL & .992 & .999 & .991 & .999 \\
\hline$V I F$ & 1.008 & 1.001 & 1.009 & 1.001 \\
\hline \multicolumn{5}{|l|}{ Zavisna varijabla ROE } \\
\hline \multicolumn{5}{|l|}{ Nezavisne varijable } \\
\hline Koeficijent determinacije $R^{2}$ & 0.165 & 0.035 & 0.058 & 0.163 \\
\hline Durbin-Watson Stat & 1.479 & 1.011 & 1.960 & 1.877 \\
\hline Udjel dugoročnih obveza & & & & \\
\hline Koeficijent regresije & -1.494 & -0.511 & -0.292 & -1.864 \\
\hline P-vrijednost & 0.072 & 0.529 & 0.805 & 0.302 \\
\hline TOL & .992 & .999 & .991 & .999 \\
\hline$V I F$ & 1.008 & 1.001 & 1.009 & 1.001 \\
\hline Udjel kratkoročnih obveza & & & & \\
\hline Koeficijent regresije & -1.407 & -0.528 & -1.474 & -3.406 \\
\hline P-vrijednost & 0.143 & 0.471 & 0.212 & 0.049 \\
\hline
\end{tabular}




\begin{tabular}{|l|c|c|c|c|}
\hline TOL & .992 & .999 & .991 & .999 \\
VIF & 1.008 & 1.001 & 1.009 & 1.001 \\
\hline
\end{tabular}

Izvor: izračun autora

Rezultati regresijske analize pokazuju da je veza između udjela kratkoročnih obveza i profitabilnosti mjerene pokazateljima neto profitna marža, ROA i ROE negativna i statistički značajna u 2012. i 2013. godini. Koeficijenti determinacije pokazuju kako je od $2.5 \%$ do $45.2 \%$ varijacija varijable profitabilnosti mjerene pokazateljima neto profitna marža, ROA i ROE objašnjeno pomoću ocijenjenih regresijskih modela.

Rezultati analize utjecaja komponenti strukture kapitala na profitabilnost dioničkih društava čiji su financijski instrumenti uvršteni na tržište kapitala u Češkoj Republici modelom višestruke linearne regresije - Model I su prikazani u Tablici 8.

Tablica 8. Rezultati analize utjecaja strukture kapitala na profitabilnost dioničkih društava u Češkoj Republici modelom višestruke linearne regresije - Model I

\begin{tabular}{|l|c|c|c|c|}
\hline Godina & $\mathbf{2 0 1 0}$ & $\mathbf{2 0 1 1}$ & $\mathbf{2 0 1 2}$ & $\mathbf{2 0 1 3}$ \\
\hline Zavisna varijabla neto profitna marža & & & & \\
\hline Koeficijent determinacije $R^{2}$ & 0.085 & 0.18 & 0.374 & 0.330 \\
Durbin-Watson Stat & 2.110 & 1.415 & 1.844 & 2.020 \\
\hline Nezavisne varijable & & & & \\
\hline Udjel temeljnog kapitala & & & & \\
Koeficijent regresije & -0.211 & 0.189 & 0.204 & -0.548 \\
P-vrijednost & 0.360 & 0.383 & 0.902 & 0.365 \\
TOL & .958 & .684 & .376 & .490 \\
VIF & 1.043 & 1.461 & 2.662 & 2.039 \\
\hline Udjel zadržane dobiti i rezervi & & & & \\
Koeficijent regresije & 0.134 & 0.467 & 2.005 & $\mathbf{1 . 9 6 0}$ \\
$P$-vrijednost & 0.591 & 0.110 & 0.401 & $\mathbf{0 . 0 5 0}$ \\
TOL & .995 & .804 & .505 & .683 \\
VIF & 1.005 & 1.244 & 1.980 & 1.464 \\
\hline Udjel dugoročnih obveza & & & & \\
Koeficijent regresije & 0.164 & -0.072 & -3.152 & -0.463 \\
P-vrijednost & 0.523 & 0.786 & 0.108 & 0.475 \\
TOL & .954 & .715 & .368 & .454 \\
VIF & 1.048 & 1.397 & 2.716 & 2.202 \\
\hline Zavisna varijabla ROA & & & & \\
\hline Koeficijent determinacije $R^{2}$ & 0.210 & 0.179 & 0.291 & 0.399 \\
Durbin-Watson Stat & 1.990 & 2.007 & 2.257 & 2.249 \\
\hline Nezavisne varijable & & & & \\
\hline Udjel temeljnog kapitala & & & & \\
Koeficijent regresije & -0.157 & -0.048 & -0.086 & -0.067 \\
P-vrijednost & 0.148 & 0.621 & 0.363 & 0.749 \\
TOL & .958 & .683 & .376 & .490 \\
VIF & 1.043 & 1.464 & 2.662 & 2.039 \\
\hline
\end{tabular}




\begin{tabular}{|c|c|c|c|c|}
\hline Udjel zadržane dobiti i rezervi & & & & \\
\hline Koeficijent regresije & 0.203 & 0.200 & 0.060 & 0.645 \\
\hline$P$-vrijednost & 0.090 & 0.123 & 0.652 & 0.050 \\
\hline$T O L$ & .995 & .818 & .505 & .683 \\
\hline VIF & 1.005 & 1.223 & 1.980 & 1.464 \\
\hline Udjel dugoročnih obveza & & & & \\
\hline Koeficijent regresije & 0.010 & -0.042 & -0.192 & -0.356 \\
\hline P-vrijednost & 0.931 & 0.720 & 0.086 & 0.125 \\
\hline TOL & .954 & .726 & .368 & .454 \\
\hline VIF & 1.048 & 1.377 & 2.716 & 2.202 \\
\hline Zavisna varijabla $R O E$ & & & & \\
\hline Koeficijent determinacije $R^{2}$ & 0.065 & 0.063 & 0.112 & 0.055 \\
\hline Durbin-Watson Stat & 2.136 & 2.325 & 2.195 & 1.958 \\
\hline Nezavisne varijable & & & & \\
\hline Udjel temeljnog kapitala & & & & \\
\hline Koeficijent regresije & -4.571 & -3.675 & -2.223 & -3.740 \\
\hline P-vrijednost & 0.593 & 0.699 & 0.616 & 0.717 \\
\hline$T O L$ & .933 & .683 & .376 & .580 \\
\hline VIF & 1.071 & 1.464 & 2.662 & 1.725 \\
\hline Udjel zadržane dobiti i rezervi & & & & \\
\hline Koeficijent regresije & 8.515 & 0.710 & 6.875 & 5.085 \\
\hline P-vrijednost & 0.368 & 0.954 & 0.626 & 0.746 \\
\hline TOL & .998 & .818 & .505 & .719 \\
\hline$V I F$ & 1.002 & 1.223 & 1.980 & 1.391 \\
\hline Udjel dugoročnih obveza & & & & \\
\hline Koeficijent regresije & -5.485 & -1.978 & -6.700 & -6.987 \\
\hline P-vrijednost & 0.570 & 0.296 & 0.196 & 0.498 \\
\hline TOL & .935 & .726 & .368 & .477 \\
\hline$V I F$ & 1.069 & 1.377 & 2.716 & 2.096 \\
\hline
\end{tabular}

Izvor: izračun autora

Rezultati analize čeških dioničkih društava su pokazali da regresorske varijable nemaju statistički značajan utjecaj na profitabilnost poslovanja. Rezultati istraživanja ukazuju na pozitivnu vezu između udjela zadržane dobiti i rezervi u ukupnom kapitalu i obvezama i profitabilnosti poslovanja, ali utjecaj nije statistički značajan osim u 2013. godini.

Rezultati analize utjecaja financiranja dugom na profitabilnost dioničkih društava čiji su financijski instrumenti uvršteni na tržište kapitala u Češkoj Republici modelom višestruke linearne regresije - Model II su prikazani u Tablici 9. 
Tablica 9. Rezultati analize utjecaja financiranja dugom na profitabilnost dioničkih društava u Češkoj Republici modelom višestruke linearne regresije - Model II

\begin{tabular}{|c|c|c|c|c|}
\hline Godina & 2010 & 2011 & 2012 & 2013 \\
\hline \multicolumn{5}{|c|}{ Zavisna varijabla neto profitna marža } \\
\hline \multicolumn{5}{|l|}{ Nezavisne varijable } \\
\hline Koeficijent determinacije $R^{2}$ & 0.207 & 0.062 & 0.341 & 0.045 \\
\hline Durbin-Watson Stat & 2.057 & 1.373 & 2.045 & 2.158 \\
\hline \multicolumn{5}{|l|}{ Udjel dugoročnih obveza } \\
\hline Koeficijent regresije & -0.178 & -0.256 & -3.781 & -0.412 \\
\hline P-vrijednost & 0.457 & 0.277 & 0.004 & 0.437 \\
\hline TOL & .998 & .995 & .977 & .927 \\
\hline$V I F$ & 1.002 & 1.005 & 1.024 & 1.079 \\
\hline \multicolumn{5}{|l|}{ Udjel kratkoročnih obveza } \\
\hline Koeficijent regresije & -0.541 & -0.093 & -0.318 & 0.276 \\
\hline P-vrijednost & 0.041 & 0.732 & 0.848 & 0.693 \\
\hline TOL & .998 & .995 & .977 & .927 \\
\hline VIF & 1.002 & 1.005 & 1.024 & 1.079 \\
\hline \multicolumn{5}{|l|}{ Zavisna varijabla ROA } \\
\hline \multicolumn{5}{|l|}{ Nezavisne varijable } \\
\hline Koeficijent determinacije $R^{2}$ & 0.065 & 0.019 & 0.213 & 0.232 \\
\hline Durbin-Watson Stat & 1.783 & 2.095 & 2.092 & 2.003 \\
\hline \multicolumn{5}{|l|}{ Udjel dugoročnih obveza } \\
\hline Koeficijent regresije & -0.044 & -0.037 & -0.140 & -0.430 \\
\hline P-vrijednost & 0.733 & 0.728 & 0.048 & 0.021 \\
\hline TOL & .998 & 983 & .977 & .927 \\
\hline$V I F$ & 1.002 & 1.018 & 1.024 & 1.079 \\
\hline \multicolumn{5}{|l|}{ Udjel kratkoročnih obveza } \\
\hline Koeficijent regresije & 0.154 & 0.058 & 0.077 & -0.012 \\
\hline$P$-vrijednost & 0.267 & 0.631 & 0.430 & 0.960 \\
\hline TOL & .998 & .983 & 977 & .927 \\
\hline VIF & 1.002 & 1.018 & 1.024 & 1.079 \\
\hline \multicolumn{5}{|l|}{ Zavisna varijabla ROE } \\
\hline \multicolumn{5}{|l|}{ Nezavisne varijable } \\
\hline Koeficijent determinacije $R^{2}$ & 0.022 & 0.072 & 0.110 & 0.039 \\
\hline Durbin-Watson Stat & 2.118 & 2.366 & 2.195 & 2.006 \\
\hline \multicolumn{5}{|l|}{ Udjel dugoročnih obveza } \\
\hline Koeficijent regresije & -4.355 & -9.326 & -23.434 & -5.674 \\
\hline P-vrijednost & 0.640 & 0.328 & 0.169 & 0.445 \\
\hline TOL & .998 & .983 & .977 & .891 \\
\hline VIF & 1.002 & 1.018 & 1.024 & 1.123 \\
\hline \multicolumn{5}{|l|}{ Udjel kratkoročnih obveza } \\
\hline Koeficijent regresije & 5.123 & 6.991 & 12.388 & 1.973 \\
\hline$P$-vrijednost & 0.603 & 0.520 & 0.603 & 0.840 \\
\hline TOL & .998 & .983 & .977 & .891 \\
\hline$V I F$ & 1.002 & 1.018 & 1.024 & 1.123 \\
\hline
\end{tabular}

Izvor: izračun autora 
Rezultati regresijske analize čeških dioničkih društava su pokazali da uz razinu signifikantnosti od 1\% varijabla udjel dugoročnih obveza ima negativan i statistički značajan utjecaj na profitabilnost mjerenu pokazateljem neto profitna marža u 2012. godini, dok udjel kratkoročnih obveza ima negativan i statistički značajan utjecaj na profitabilnost mjerenu pokazateljem neto profitna marža u 2010. godini. Udjel dugoročnih obveza u ukupnom kapitalu i obvezama ima negativan i statistički značajan utjecaj na profitabilnost mjerenu pokazateljem ROA u 2012. i 2013. godini.

\section{DISKUSIJA}

Rezultati analiziranih modela za dionička društva čiji su financijski instrumenti uvršteni na tržište kapitala u Hrvatskoj, Sloveniji i Češkoj Republici su statistički korektni sa stajališta polaznih pretpostavki koje su u potpunosti ispunjene.

Rezultati analize utjecaja financijske strukture na performansu profitabilnosti su u skladu s dosadašnjim istraživanjima utjecaja financijske strukture na profitabilnost poduzeća i ukazuju da povećanje udjela dugoročnih i kratkoročnih obveza u financijskoj strukturi dovodi do smanjenja profitabilnosti hrvatskih dioničkih društava jer veći udjeli duga impliciraju više troškove financijskih poremećaja i troškove agenata povezane uz financiranje dugom koji uzrokuju smanjenje profitabilnosti. Rezultati za dionička društva u Republici Hrvatskoj su konzistentni s rezultatima: Gleason et al. (2000), Eriotis et al. (2002), Goddard et al. (2005) i Nunes et al. (2009) koji su dokazali da stupanj zaduženosti ima negativan utjecaj na performansu profitabilnosti. Dobiveni rezultati za dionička društva u Republici Hrvatskoj su konzistentni s rezultatima dosadašnjih empirijskih istraživanja u Republici Sloveniji i Češkoj Republici: Gabrijelčić et al. (2013), Chandrapana i Klapkova (2013) te Močnik i Širec (2015) koji su dokazali da između financiranja dugom i profitabilnosti postoji negativna veza.

U istraživanju je utvrđeno da je varijabla udjel zadržane dobiti i rezervi u ukupnom kapitalu i obvezama statistički značajna za ostvarenje i unapređenje profitabilnosti dioničkih društava u Hrvatskoj. Povećanjem udjela zadržane dobiti u strukturi kapitala, kao najkvalitetnijeg oblika dugoročnog financiranja koji ne stvara troškove kamata i troškove emisije, hrvatska dionička društva mogu utjecati na ostvarenje i povećanje profitabilnosti koja je ključna za osiguranje dugoročnog opstanka i razvoj dioničkih društava. Zadržavanje dobiti omogućuje nova investicijska ulaganja i privlačenje tuđeg kapitala. Financiranje dugotrajne imovine samo vlastitim kapitalom ograničava ekspanziju i razvoj poduzeća, a može biti uzrok zaostajanja poduzeća, pa je razumno takvu imovinu financirati i dugoročnim dugom (Kontuš, 2011).

Istraživanje utjecaja varijabli financiranja dugom na profitabilnost slovenskih dioničkih društava je pokazalo da udjeli dugoročnih i kratkoročnih obveza imaju negativan utjecaj na profitabilnost mjerenu pokazateljima neto profitna marža, ROA i ROE. Rezultati istraživanja za dionička društva u Republici Sloveniji su konzistentni s rezultatima: Gabrijelčić et al. (2013), Chandrapana i Klapkova (2013) te s rezultatima Močnik i Širec (2015) koji su dokazali da stupanj zaduženosti ima negativan utjecaj na profitabilnost poduzeća. 
Povećanjem udjela zadržane dobiti i rezervi u ukupnom kapitalu i obvezama, odnosno financiranjem iz interno generiranih sredstava, slovenska dionička društva mogu povećati profitabilnost poslovanja. Povećanje udjela dugoročnih i kratkoročnih obveza u ukupnom kapitalu i obvezama dovodi do smanjenja profitabilnosti slovenskih dioničkih društava čiji su financijski instrumenti uvršteni na tržište kapitala.

Rezultati analize čeških dioničkih društava su pokazali da regresorske varijable udjel zadržane dobiti i rezervi i udjel dugoročnih obveza nemaju signifikantan utjecaj na profitabilnost poslovanja. Udjel zadržane dobiti i rezervi u ukupnom kapitalu i obvezama ima pozitivan utjecaj na profitabilnost čeških dioničkih društava mjerenu pokazateljima neto profitna marža, ROA i ROE, ali utjecaj nije statistički značajan. Udjel dugoročnih obveza ima negativan utjecaj na profitabilnost čeških dioničkih društava mjerenu pokazateljima neto profitna marža i ROE, ali utjecaj nije statistički značajan.

Konačni uzorak uključuje hrvatska, slovenska i češka dionička društva čiji su financijski instrumenti uvršteni na tržište kapitala, te sadrži samo velika poduzeća. Slijedom toga analiza utjecaja varijable veličina poduzeća na profitabilnost poslovanja nije obuhvaćena ovim istraživanjem.

Zaključno se može ustvrditi da se utjecaj financijske strukture na performansu profitabilnosti ne može istražiti samo kao utjecaj ukupne zaduženosti na profitabilnost poslovanja, što se učestalo primjenjuje u empirijskim istraživanjima jer je u ovom istraživanju utvrđeno da udjel zadržane dobiti i rezervi u ukupnom kapitalu i obvezama ima pozitivan i statistički značajan utjecaj na performansu profitabilnosti. Stoga se varijable vlastitog kapitala ne mogu isključiti pri istraživanju. Dionička društva čiji su financijski instrumenti uvršteni na tržište kapitala u Hrvatskoj mogu smanjenjem udjela dugoročnih obveza i kratkoročnih obveza u ukupnom kapitalu i obvezama utjecati na povećanje profitabilnosti poslovanja. Povećanjem udjela dugoročnog i kratkoročnog duga smanjuje se profitabilnost poslovanja jer financiranje dugom stvara troškove financiranja koji uključuju troškove financijskih poremećaja i troškove agenata povezane uz financiranje dugom. Troškovi financiranja smanjuju dobitak i profitabilnost dioničkih društava. S aspekta utjecaja strukture kapitala na profitabilnost poslovanja potrebno je spoznati najbolju kombinaciju dugoročnog duga, povlaštenih dionica i običnih dionica kojom će se uz najniže troškove financiranja ostvariti najviša profitabilnost.

Dionička društva čiji su financijski instrumenti uvršteni na tržište kapitala u Republici Hrvatskoj moraju voditi novu i napredniju financijsku politiku koja će se temeljiti na znanstvenim spoznajama o upravljanju dugoročnim izvorima financiranja te koja će stvarati pretpostavke za vođenje uspješne politike profitabilnosti poslovanja. Upravljanje dugoročnim financiranjem treba težiti određivanju optimalne veličine i strukture dugoročnog duga. Politika profitabilnosti treba težiti generiranju pozitivnog financijskog rezultata koji će omogućiti veće zadržavanje dobiti, kao najkvalitetnijeg izvora financiranja. Zadržana dobit omogućuje nova investicijska ulaganja i privlačenje tuđeg kapitala. Financiranje dugotrajne imovine samo vlastitim kapitalom u uvjetima niskih kamatnih stopa na dugoročne kredite ograničava ekspanziju i razvoj dioničkih društava, te može biti uzrok zaostajanja dioničkih društava, pa je razumno takvu imovinu financirati i tuđim kapitalom. 
Kriza COVID-19 bi trebala imati utjecaja na ostvarivanje i smanjenje profitabilnosti dioničkih društava čiji su financijski instrumenti uvršteni na tržište kapitala te na povezanost komponenti strukture kapitala i profitabilnosti dioničkih društava. Financijska poluga sugerira da vanjsko financiranje povećava dobit sve dok je postotak dobiti veći od kamatne stope na posuđeni novac. Stoga nije vjerojatno da će za vrijeme i nakon pandemije COVID-19 postotak ostvarene dobiti dioničkih društava biti veći od kamatnih stopa na posuđeni novac odnosno da će financiranje dugom povećati dobit dioničkih društava.

\section{ZAKLJUČAK}

U ovom je radu istražen utjecaj financijske strukture na profitabilnost dioničkih društava. Nakon provođenja regresijske cross sectional analize utjecaja komponenti strukture kapitala na profitabilnost hrvatskih dioničkih društava rezultati istraživanja su pokazali da varijabla udjel zadržane dobiti u ukupnom kapitalu i obvezama ima statistički značajan utjecaj na performansu profitabilnosti. Varijable udjel dugoročnog duga i udjel kratkoročnog duga imaju negativan utjecaj na profitabilnost hrvatskih dioničkih društava, pa povećanje udjela dugoročnog i kratkoročnog duga dovodi do smanjenja profitabilnosti hrvatskih dioničkih društava.

Rezultati regresijske analize utjecaja komponenti strukture kapitala na profitabilnost slovenskih dioničkih društava su pokazali da se povećanjem udjela zadržane dobiti u strukturi kapitala dioničkih društava može povećati njihova profitabilnost dok povećanje udjela dugoročnog i kratkoročnog duga u financijskoj strukturi dovodi do smanjenja profitabilnosti slovenskih dioničkih društava. Rezultati regresijske analize čeških dioničkih društava čiji su financijski instrumenti uvršteni na tržište kapitala su pokazali da varijable financijske strukture nemaju statistički značajan utjecaj na profitabilnost poslovanja. Time je djelomično potvrđena hipoteza istraživanja da struktura kapitala utječe na profitabilnost dioničkih društava u odabranim zemljama članicama Europske unije.

Utjecaj financijske strukture na profitabilnost dioničkih društava je različit u različitim institucionalnim okruženjima jer obilježja institucionalnog okruženja odnosno obilježja financijskog sustava, pravnog sustava i poreznog sustava određuju utjecaj financijske strukture na profitabilnost dioničkih društava. Ako dionička društva ostvaruju veće prinose u usporedbi s troškovima duga, veći udjeli duga u financijskoj strukturi mogu dovesti do povećanja prinosa koje ostvaruju dioničari, pa financiranje dugom pruža dioničkim društvima veći potencijal za razvoj, omogućuje ekspanziju i povećanje profitabilnosti poslovanja. Povećanje udjela duga u financijskoj strukturi smanjuje troškove agenata povezane uz financiranje vlastitim kapitalom koji mogu nepovoljno utjecati na financijske performanse. sljedećem:

Znanstveni doprinosi istraživanja provedenog u ovom radu se ogledaju u

- Utvrđen je utjecaj pojedinačnih komponenti strukture kapitala na profitabilnost dioničkih društava u odabranim zemljama članicama Europske unije. 
- Odabirom komponenti strukture kapitala dionička društva u odabranim zemljama članicama Europske unije mogu utjecati na održavanje i unapređenje profitabilnosti poslovanja. Povećanjem udjela zadržane dobiti u ukupnom kapitalu i obvezama dionička društva mogu utjecati na povećanje i unapređenje njihove profitabilnosti.

- Rezultati empirijskog istraživanja dokazuju da se utjecaj strukture kapitala na performansu profitabilnosti ne može istražiti samo kao utjecaj ukupne zaduženosti na profitabilnost poslovanja, što se učestalo primijenjuje $u$ empirijskim istraživanjima jer varijabla udjel zadržane dobiti ima statistički značajan utjecaj na profitabilnost poslovanja, te se ne može izostaviti pri istraživanju utjecaja strukture kapitala na performansu profitabilnosti.

- Struktura kapitala dioničkih društava u odabranim zemljama članicama Europske unije se može smatrati relevantnom jer je utvrđen statistički značajan utjecaj komponenti strukture kapitala odnosno udjela zadržane dobiti na performansu profitabilnosti.

Relativno male vrijednosti koeficijenata multiple linearne determinacije ostavljaju prostor za daljnja istraživanja. Ograničenje ovog istraživanja i izazovno područje za daljnja istraživanja svakako predstavljaju ostale karakteristike dioničkih društava: investicije, veličina poduzeća, rast i likvidnost koje imaju utjecaja na performansu profitabilnosti, a nisu obuhvaćene ovim istraživanjem. Stoga procijenjenim modelima valja pristupiti kao inicijalnom istraživanju odrednica profitabilnosti dioničkih društava u zemljama članicama Europske unije. Buduća istraživanja utjecaja strukture kapitala na profitabilnost dioničkih društava u zemljama članicama Europske unije bi trebala uključivati dionička društva iz različitih sektora i dionička društva koja koriste različite poslovne modele zbog njihovog utjecaja na strukturu kapitala i profitabilnost poslovanja.

\section{LITERATURA:}

1. Baum, C.F., Schafer, D., Talavera, O., (2006), The Effects of Short-Term Liabilities on Profitability, Boston College Working Papers in Economics 636, Boston College.

2. Berger, A.N., Bonnacorsi di Patti, E., (2006), Capital Structure and Firm Performance: A New Approach to Testing Pecking Order Theory and an Application to Banking Industry, Journal of Banking and Finance, 4.

3. Chandrapala, P., Knapkova, A., (2013), Firm Specific Factors and Financial Performance of Firms in the Czech Republic, Acta Universitatis Agriculturae et Silviculturae Mendelianae Brunensis, LXI, 7.

4. Eriotis, N.P., Franguoli, Z., Neokosmides, Z. V., (2002), Profit Margin and Capital Structure: An Empirical Relationship, The Journal of Applied Business Research, 18. 
5. Gabrijelčić, M., Herman, U., Lenarčič, A., (2013), Debt Financing and Firm Performance before and during the Crisis: Micro-Financial Evidence from Slovenia, http://papers.ssrn.com/sol3/papers.cfm?abstract_id=2338637.

6. Gleason, K. C., Mathur, L. K., Mathur, I., (2000), The Interrelationship between Culture, Capital Structure and Performance: Evidence from European Retailers, Journal of Business Research, 50 (2).

7. Goddard, J., Tavakoli, M., Wilson, J., (2005), Determinants of profitability in European manufacturing and services, Applied Financial Economics, 15.

8. Kebewar, M., (2012), The Effect of Debt on Corporate Profitability: Evidence from French Service Sector, Working Papers, Halshs-00766758, HAL.

9. Kontuš, E., (2011), Kratkoročno financiranje i njegove implikacije na solventnost i profitabilnost poduzeća, Ekonomska misao i praksa, 2.

10. Kontuš, E., (2012), Short-term financing management, International Journal of Management Cases, 14 (4).

11. Kontuš, E., (2018), Financing Management of Companies, In: Dominici G., Del Giudice M., Lombardi R. (eds.), Governing Business Systems, Cham: Springer.

12. Margaritis, D., Psillaki, M., (2010), Capital Structure, equity ownership and firm performance, Journal of Banking and Finance, 34(7).

13. Močnik, D., Širec, K., (2015), Determinants of a Fast Growing Firm's Profits: Empirical Evidence for Slovenia, Scientific Annals of the University of Iasi, 62(1).

14. Nunes, P.J., Serrasqueiro, Z.M., Sequeira, T.N., (2009), Profitability in Portuguese service industries: a panel data approach, The Service Industries Journal, 29.

15. Vatavu, S., (2015), The Impact of Capital Structure on Financial Performance in Romanian Listed Companies, Procedia Economics and Finance, 32.

16. Weill, L., (2008), Leverage and Corporate Performance: Does Institutional Environment Matter? Small Business Economics, 30(3). 


\title{
THE IMPACT OF CAPITAL STRUCTURE ON THE PROFITABILITY: A CASE OF CROATIAN, SLOVENIAN AND CZECH LISTED COMPANIES
}

\author{
Eleonora Kontuš
}

\begin{abstract}
Summary
The main purpose of the study was to investigate the impact of capital structure on the profitability of listed companies in the members of European Union. The empirical research was based on a sample of Croatian, Slovenian and Czech listed companies and multiple linear regression on cross sectional data was used for research data analysis. The research findings indicate that the retained earnings to capital ratio has a positive and significant impact on the profitability of listed companies in the Republic of Croatia as well as long-term debt to capital and short-term debt to capital ratios have a negative impact on the profitability of listed companies. The empirical results show that the retained earnings to capital ratio has a positive impact on the profitability of listed companies in the Republic of Slovenia while long-term debt to capital and short-term debt to capital ratios have a negative impact on the profitability of listed companies. The results indicate that the capital structure affects the profitability of listed companies differently in the Czech Republic. This study makes several contributions to the field: the impact of capital structure components on corporate profitability is determined as well as the capital structure decisions affect corporate profitability of listed companies in the members of European Union. The capital structure of listed companies in the members of European Union is relevant for the profitability because the retained earnings to capital ratio has a statistically significant impact on the profitability of listed companies. profitability.

Keywords: capital structure; equity; retained earnings; long-term debt;
\end{abstract}

